\title{
Climate Madrasah Tsanawiyah in Bandar Lampung (Analysis on security aspects)
}

\author{
Erfina ${ }^{1}$, Wan Jamaluddin ${ }^{2}$, Siti Patimah ${ }^{3}$, Andi Thahir ${ }^{4}$ \\ \{3waghei@gmail.com¹, averro99@yahoo.com ${ }^{2}$, sitipatimah@radenintan.ac.id ${ }^{3}$, \\ andithahir@radenintan.ac.id $\left.{ }^{4}\right\}$
}

Postgraduate student of the Islamic Education Management Study Program, UIN Raden Intan Lampung ${ }^{1}$, Senior Lecturer in Islamic Education Management Postgraduate Program at UIN Raden Intan Lampung ${ }^{2}$, Senior Lecturer in Islamic Education Management Postgraduate Program at UIN Raden Intan Lampung ${ }^{3}$, Senior Lecturer in Islamic Education Management Postgraduate Program at UIN Raden Intan Lampung ${ }^{4}$

\begin{abstract}
A positive and conducive climate for the madrasah will impact the achievement of the educational goals of the madrasah in an effective and efficient manner. Therefore, it is necessary to continue research on the climate of the Madrasa Tsanawiyah in Bandar Lampung, which is devoted to the security aspect. This study uses a qualitative approach which aims to analyze the climate of the tsanawiyah madrasah on the security aspect. The results of this study revealed that Madrasah Tsanawiyah in the city of Bandar Lampung from aspects of emotional physical and social security has a positive and conducive climate.
\end{abstract}

Keywords: madrasah climate, security

\section{Introduction}

The Madrasah is one of the national education sub-systems. As a subsystem of national education, madrasah are not immune to the problems encountered by national education in general. The Ministry of Religious Affairs in the area of Madrasah explains more specifically that the problems faced by Madrasah include the lack of educational climate in Madrasah, such as: (1) poor quality of physical facilities as indicated by damaged buildings of Madrasah , (2) poor possession and use of learning facilities, (3) incomplete libraries, (4) non-standard laboratories, (5) inadequate use of information technology [1].

The National Accreditation Council of Schools / Madrasah (BAN-S/M) accredits 62,365 schools or madrasah throughout Indonesia, at SD, MI, SMP, MTs, SMA, MA, SMK, SLB, SDLB, SMPLB levels, at SMALB levels. Of these, 1,416 schools were not accredited. Of the 62,365 , the gap at rank A was 15,805 or with a percentage of $25.34 \%$. Its B rating is $33,827.54 .24 \%$. Its $C$ rating is 11,317 . $18.15 \%$. And not accredited 1416. $2.27 \%$ of 62,365 , distributed at rank A of 15,805 or with a percentage of $25.34 \%$. Its B rating is $33,827.54 .24 \%$. Its $C$ rating is $11,317.18 .15 \%$. And not 1416 accredited. $2.27 \%$. The data issued show that out of 22,035 MI and 10,365 MTs, only about $20 \%$ can be considered good. While the remaining $80 \%$ have the opposite condition. To see the state of these madrasas, it can be seen under aspects of management, funding, geographic location and parents. Not to mention the problem of teachers who miss the game (bad room) and underqualified or we can say that they are not yet achievable. Data from the Ministry of Religion indicates that nearly 60 percent of public madrasah teachers are classified as inadequate. This figure is $80 \%$ for private madrasah. Teachers who are eligible but have the wrong room (mismatch) 20 percent, and the remaining 20 percent who are truly worthy and match between their scientific discipline and the field of study being taught [2]. The qualification of MTs teachers who have met the national education standards is 59.9 percent, even less than the percentage of SMP / MTs teachers who have met the national education standard, which is 63.3 percent [3]. 
The quality of the teaching of the madrasah, in particular in MTs, in particular in Bandar Lampung, on the basis of the data of the EMIS for the school year 2019/2020, we know that of the 30 MTs of Bandar Lampung, there are a 9 (nine) or $30 \%$ of MTs that obtain C accreditation and only 2 (two) or $6.7 \%$ of MTs that received A accreditation. There were even MTs that had not been accredited. These data indicate that the quality of education in Madrasah Tsanawiyah in the city of Bandar Lampung is still low and needs improvement efforts to make it even better.

Seeing these problems, the director general of Islamic education of the ministry of religion gave a political direction to improve the quality of education in madrasah, which includes five aspects, including the effectiveness of the educational climate in the madrasah/ school environment [4]. The research results of Budi Susanto, et al., Also found that school climate has a partial and significant effect on the quality of education in MT schools in the district of Tarowang, Jeneponto Regency [5]. Shindler et al., Examined the relationship between school climate and student achievement scores in urban school districts in five states $(\mathrm{N}=230)$. Many educators see school climate and student achievement as separate considerations. However, the results of this study indicate that climate and student achievement are closely related. In fact, the quality of the climate seems to be the most predictive factor of any school's ability to promote student success [6].

Based on this explanation, it is clear that the climate of the madrasah is something that should be taken as an indicator of the quality of education in the madrasa. This means that if you want to improve the quality of madrasah education, it is necessary to improve and improve the climate of the madrasah so that it becomes more positive and conducive. Thus, it can be said that the climate of the madrasah is something that requires the attention of a director of the madrasah as responsible for education, as the climate of the madrasah affects the behavior of teachers, staff of the madrasah and students. The state or atmosphere of the madrasah is calm and comfortable, suitable for the learning process, which is considered to be a favorable madrasah climate. A conducive climate for madrasah, both physical and nonphysical, is the basis for effective and productive learning.

The climate of the madrasah has a huge influence on achieving the goals of the madrasah effectively and efficiently. A good madrasah climate will support the learning activities carried out by teachers and students. The better the climate in the madrasa, the better the learning activities carried out by teachers and students. It can therefore be said that a favorable madrasah climate is a prerequisite for the implementation of effective learning.

One aspect of the madrasah climate that is important to pay attention to is that of security. Security is a state of safety and security. Safety not only prevents pain or injury, but safety can also protect individuals in their activities, reduce stress, and improve overall health. According to Cohen, the climate of the madrasah in the security aspect comprises two aspects, namely (1) the physical aspects and (2) the social emotional aspects. According to Cohen, the physical safety aspects of schools include the safety rules and standards for the physical facilities of schools. School climate in the aspect of emotional social security includes attitudes towards differences, attitudes and responses to bullying, conflict resolution, and belief in school rules [7]. The need for emotional physical and social security is the need to protect oneself from dangers that threaten physical and psychological health, which in this discussion will focus on safety or the provision of a safe environment.

The results of the pre-survey on the climate of the Madrasah Tsanawiyah on the security aspect in the city of Bandarlampung, show that the conditions of the organizational climate in the Madrasah Tsanawiyah in Bandarlampung still need to be improved and improved. Therefore, the researchers are interested in further researching the climate of the tsanawiyah madrasah in Bandarlampung, so that efforts can be found to improve the climate of the madrasah in accordance with the conditions of the tsanawiyah madrasah in Bandarlampung. 


\section{Literature Review}

\subsection{Climatic and security aspects of the Madrasah \\ 2.1.1 Climate Madrasah}

The climate of the Madrasah is a series of characteristics of the working environment, which are evaluated directly or indirectly by the employees which are considered to be the main factor influencing the behavior of the employees [8]. According to the National School Climate Center (NSCC), school climate is defined as "school climate refers to the quality and character of school life. School climate is based on models of the experience of students, parents and school staff of school life and reflects norms, goals, values, interpersonal relationships, teaching and learning practices and organizational structures [9]. Haynes, cited by Hoffman et.al, defines school climate as "the quality and consistency of interpersonal interactions within the school community that influence children's cognitive, social and psychological development" [10]. Based on some of these opinions, it is understood that the climate of the madrasa is factors external to humans, both physical and non-physical in an organization that directly or indirectly affect the behavior of people in the organization, which is characterized by a feeling of comfort, job satisfaction and atmosphere full of passion.

A conducive madrasah climate is a prerequisite for the implementation of an effective teaching and learning process. A safe and orderly madrasah environment, high optimism and the expectations of the citizens of the madrasa, the health of the madrasa and student-centered activities are examples of a madrasah climate that fosters enthusiasm for learning students. A conducive madrasah climate is a prerequisite for the implementation of an effective teaching and learning process. A safe and orderly madrasah environment, high optimism and expectations of the citizens of the madrasa, the health of the madrasah and student-centered activities are examples of a madrasah climate that fosters enthusiasm for learning students.

The criteria for identifying the climate of the madrasah are (1) quality of leadership, (2) level of confidence, (3) upward and downward communication, (4) feeling of doing useful work, (5) accountability, (6) fair rewards, (7) reasonable professional pressure, (8) scope for control, (9) sensible structure and bureaucracy, and (10) employee involvement [11]. Ramsey, et al., Show that school climate integrates many aspects of school environment and school life, such as a) facilities and buildings; b) the demographics of learners and their social characteristics; c) teachers, administrators and staff; d) school policies, values and regulations; e) the types of interactions that occur between students, teachers, staff and parents [12]. Another view was expressed by Cohen that the climatic dimensions of madrassas include (1) security aspects; physical and socio-emotional aspects, (2) teaching and learning activities; Quality of learning, socio-emotional and ethical learning, leadership, (3) Attitudes of school members; respect diversity, collaboration, morals and connectivity, (4) the institutional environment [7].

Based on some of these opinions, it can be concluded that there are two dimensions of the climate of the madrasah, namely (1) the physical dimensions, covering various facilities and infrastructures that support the learning activities in the madrasah, the pupil / teacher ratio in the classroom, availability of human resources, safety and comfort. (2) non-physical dimensions, including social dimensions, such as the quality of interpersonal relationships between madrasah directors, teachers, staff and students; contribution of teachers, staff and students to decision-making, remuneration and rewards, support and cooperation of the school. The academic dimension includes: the quality of learning that is creative, innovative and fun; professional development of teachers; learning that takes into account the interests and talents of students; actively involve the parents of the students; discipline of teachers, staff and students; and monitor student progress.

\subsubsection{Security Aspects}

According to Cohen, the climate of the madrasah in the security aspect comprises two aspects, namely (1) the physical aspects and (2) the social and emotional aspects [7]. School is 
the field of education, in which there is a process of education, teaching and training. School as a field of education must ensure the implementation of a good educational process. The right conditions for this process are conditions of security, calm, order and order, mutual respect and good social relations. This means that both physical and social and emotional security conditions in the school will promote the fluidity of the educational process in schools.

Maintaining physical security involves reducing or preventing threats to the body or life. These threats can be diseases, accidents, dangers to the environment. According to Cohen, the physical safety aspects of schools include regulations and safety standards for the physical facilities of schools [7]. The aspect of physical safety of schools in the form of school rules is important. A conducive madrasah climate requires school regulations, namely rules for teachers, students, and other regulations deemed necessary. The established rules will lead to discipline, which is very necessary in the process of teaching and learning. This is because the school rules will create a sense of fun to learn and improve social relationships [13].

In addition to school discipline, the climate of the madrasah is physical, seen from the safety aspect of school facilities. Limon's research findings revealed that inadequate and safe quality of school facilities would affect students' work and learning outcomes [14]. McGowen also pointed out that the condition of school facilities that meet safety, health and completeness standards will affect student learning outcomes, discipline, attendance and the comfort level of students and teachers. to feel at home to learn and teach at school [15].

Safe school facilities are school facilities with buildings, their contents, and the surrounding yard that meet safety, health, facility requirements, including the eligibility of children with special needs, comfort, and safety [16]. Based on this understanding, it is understood that a safe school facility is if the school's facilities and infrastructure meet predetermined standards, so that it impacts the comfort and safety of the community. school.

The climate of the madrasah in the security aspect is also seen in the emotional social aspect. According to Cohen, the school climate in the aspect of emotional social security includes attitudes towards differences, attitudes and responses to bullying, conflict resolution, and belief in school rules [7]. Based on Cohen's opinion, it is understood that the climate of the madrasah can also be seen from the aspect of the social and emotional security of the residents of the school, where school members believe that there is no discrimination against various differences, strongly oppose any act of harassment, any conflict that arises is promptly answered and resolved, and all school members trust and obey all the rules of the 'school.

\section{Methods}

This type of research is a descriptive study using a qualitative approach. This research was conducted at Madrasah Tsanawiyah in the city of Bandarlampung, Lampung province, totaling 30 MTs with details of 2 (two) MT with state status and 28 MTs with private status. The data sources for this qualitative study were purposely selected and were a snowball sampling, including the head of MTs and their representatives, teachers, parents and students of MTs Bandarlampung. The data collection tools for this study were interviews, observation and documentation. The data analysis technique used in qualitative research is inductive, that is, an analysis based on the obtained data, then a specific relationship model is developed. In this study, to obtain the validity of the data, triangulation was used.

\section{Result and Discussion}

Based on the results of the data collection, it was found that the climate of the Tsanawiyah Madrasah in Bandarlampung by providing security on the physical aspects was generally good, as (1) each madrasah had an order and executed these rules correctly firmly and systematically, (2) respecting the safety standards of the school's physical facilities that 
meet the safety, health and accessibility standards, (3) the environment of the madrasah is equipped with a system security in emergency situations and the presence of security personnel. Based on these results, from several climates of madrasah on these safety indicators, there are still a number of things to improve, namely (1) to provide written information on the rules of the madrasah which are placed in places easily visible and read by all members of the madrasa (2)) the existence of a security staff who watches over the state of the environment of the madrasah, which is sufficient to give a feeling of security to all members of the madrasah.

These findings are relevant to Filardo's research findings that the lack of physical safety in schools is a serious problem in student learning and achievement [17]. Dwi Puryanto's research findings revealed that the quality of school facilities influenced the decision to choose the school's educational services. This means that the quality of school facilities is one of the things that becomes a consideration for someone in choosing their educational services, as the quality of school facilities will provide a sense of comfort and security to its citizens [18]. The results of Reverend Mbanwi Pascaline Enjoh's research also revealed that all respondents to his research agreed that safe school facilities would improve teaching and learning. Because safe school facilities provide a sense of comfort to its citizens. The poor quality of the school's physical facilities can lead to an increase in student absenteeism, a decline in student and teacher performance, due to a reduced sense of comfort [19]. Other studies have also shown that the condition of physical facilities in schools that meet safety and health standards has a positive relationship with students' academic performance [20].

Based on these findings and opinions, it shows that the infrastructure security of Madrasah Tasanawiyah in the city of Bandarlampung greatly affects its residents. Madrasah that have security in their facilities and infrastructure will make madrasah residents feel comfortable in performing all of their activities, so this will directly affect their performance. Unsanitary school buildings and school facilities will make madrasah residents uncomfortable to carry out all madrasah activities, which of course will disrupt the climate of the madrasah which is not conducive.

Another conclusion is that most tsanawiyah madrasah in Bandarlampung ensure the security of the socio-emotional aspects of their citizen madrasa by taking measures (1) respecting differences regardless of ethnicity, gender or social status, (2) reactive and firm in the face of all acts of intimidation. with guidance and counseling (BK), cooperation between teachers, leaders, parents and the community, (3) resolve internal and external conflicts immediately, (4) believe that the rules of the madrasah have a positive effect on the citizens of the madrasa. Some of those things that still need to be improved is respect for differences between students. The results of the interview showed that most teachers in Tsanawiyah Madrasah did not appreciate the differences between the students, so that it took effort on the part of the leaders and the teachers themselves not only to pay attention to intelligent and accomplished students. Other students should also have opportunities and encouragement to work, so that the climate in the madrasah becomes more positive and full of enthusiasm for learning.

These findings are relevant to Darney's research that the lack of a sense of security in the socio-emotional situation of students, one of which is due to bullying, will have a long-term effect on Sukarame. During their time at school, students will feel uncomfortable and secure, which will make them lazy and may not even want to go to school [21]. Jennifer Godman's research results also revealed that a respectful and safe school is a school that can suppress oppressive actions that will lead to an uncomfortable and negative school climate for student learning [22]. Karim's research confirms that the ability of schools to overcome various conflicts that interfere with the social and emotional lives of students will improve the social and academic outcomes of the term Sukarame, thereby creating a harmonious climate in the term Sukarame [23]. Even Wani's research confirms that social emotional turmoil in a society causes fear, life becomes dangerous, and always feels threatened by danger [24]. 
The results and opinions indicate that the social and emotional security of the citizens of the madrasa will greatly affect their citizens. Madrasah capable of providing social and emotional security to their madrasah dwellers will make madrasah dwellers feel comfortable and safe in carrying out all their activities, so this will directly affect their performance. Madrasah which are not able to provide social and emotional peace and security of the inhabitants of the madrasah will make the inhabitants of the madrasah uncomfortable to carry out all the activities of the madrasah, which well sure will disturb the climate of the madrasah and become unfavorable.

Based on these results, it can be concluded that the madrasah tsanawiyah in the city of Bandar Lampung, viewed from the aspects of physical and social emotional security, can be classified as having a positive and conducive climate. Indeed, the tsanawiyah madrasah in the city of Bandarlampung has facilities and infrastructure that meet safety standards and are able to provide social and emotional security to the inhabitants of the madrasa. Thus, the climate of the tsanawiyah madrasah in the city of Bandar Lampung, seen from the aspects of physical and social emotional security, generally shows a positive and conducive climate. This means that all members of Madrasah Tsanawiyah in Bandarlampung city generally feel safe and comfortable in carrying out their activities, as Madrasa Tsanawiyah in Bandarlampung city is able to provide them with security in both the emotional physical and social aspects of the inhabitants of the madrasah.

\section{Conclusion}

Based on the research results, it can be concluded that the climatic conditions of the Tsanawiyah Madrasah in Bandarlampung are seen from the safety indicators, both physical and social, emotional, generally classified as good. This means that from the point of view of emotional physical and social security, all residents of the tsanawiyah madrasah in Bandarlampung feel secure, both on the social physical and emotional aspects, thus creating a positive and conducive madrasah climate. to achieve the goals of madrasah education effectively and efficiently.

\section{References}

[1] Departemen Agama RI, Laporan Tahunan 2008. Jakarta: Direktorat Jenderal Pendidikan Islam, 2017.

[2] A. Murtadho, "Berbasis Manajemen Mutu," J. Forum Tarb., vol. 10, no. 1, pp. 91-112, 2012.

[3] Departemen Agama RI, Analisis Statistik Data Pendidikan Islam. Jakarta: Direktorat Jenderal Pendidikan Islam, 2008.

[4] I. Bafadal, Peningkatan Profesionalisme Guru MI Dalam Rangka ManajemenMutu Berbasis Madrasah. Jakarta: Bumi Aksara, 2014.

[5] B. Susanto, "The Influence Of Headmaster Leadership , School Climate And Teacher Competence Toward Education Quality In Mts Jeneponto Regency," J. Manage., vol. 1, no. 2, pp. 23-39, 2018.

[6] J. Shindler, A. Jones, A. D. Williams, C. Taylor, and H. Cardenas, "The school climate-student achievement connection: if we want achievement gains, we need to begin by improving the climate," J. Sch. Adm. Res. Dev., vol. 1, no. 1, pp. 9-16, 2016.

[7] J. Cohen, "School Climate : Research , Policy," Teach. Coll. Rec., no. January 2009, 2017.

[8] Syaiful Sagala, Memahami Organisasi Pendidikan. Bandung: Alfabeta, 2009.

[9] A. Thapa, J. Cohen, S. Guffey, and A. Higgins-D'Alessandro, A Review of School Climate Research, vol. 83, no. 3. 2013.

[10] Lorry L. Hoffman, "On Improving School Climate: Reducing Reliance on Reward andPunishment," Improv. Sch. Clim., vol. 5, no. 1, pp. 13-24, 2015.

[11] Keith Davis and Jhon W. Newstorm, Perilaku dalam Organisasi. Jakarta: Erlangga, 2008.

[12] C. M. Ramsey, A. P. Spira, J. M. Parisi, and G. W. Rebok, "School climate: perceptual differences between students, parents, and school staff," Sch. Eff. Sch. Improv., vol. 27, no. 4, pp. 629-641, 2016. 
[13] L. S. Hadianti, "TERHADAP KEDISIPLINAN BELAJAR SISWA ( Penelitian Deskriftif Analisis di SDN Sukakarya II Kecamatan samarang Kabupaten Garut )," J. Pendidik. Univ. Garut, vol. 02, no. 1, pp. 1-8, 2008.

[14] M. R.

Limon,

“The_Effect_of_the_Adequacy_of_School_Facilities_on_Students'_Performance_and_Achieve

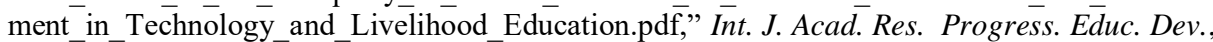
vol. $\overline{5}$, no. 1, pp. $45-\overline{58}, 2016$.

[15] R. S. McGowen, "The Impact of school facilities on student achievement, attendance, behavior, completion rate, and teacher turnover rate in selected Texas high schools," Texas A \& M University, 2007.

[16] Gogot Suharwoto, Modul 1; Pilar 1 Fasilitas Sekolah Aman. Jakarta: Kemendikbud, 2015.

[17] M. Filardo, "Good buildings, better schools: An economic stimulus opportunity with longterm benefits."

[18] D. Puryanto, "Pengaruh Kualitas Fasilitas, Kualitas Pembelajaran dan Lokasi Terhadap Keputusan Memilih Jasa Pendidikan di SMPIT Global Insani Islamic School-Bekasi,” J. Ekon. dan Bisnis STIE YPN, vol. VIII, no. 3, pp. 31-45, 2015.

[19] R. M. P. Enjoh, "The Impact of School Facilities on Teaching and Learning in Presbyterian Secondary Schools in the SW of Cameroon," Int. J. Trend Sci. Res. Dev., vol. Volume-2, no. Issue-6, pp. 1427-1437, 2018.

[20] A. Fagbohunka, "Infrastructural facility and the students' academic performance - A critique," Indones. J. Geogr., vol. 49, no. 1, pp. 11-16, 2017.

[21] C. Darney, G. Howcroft, and L. Stroud, "the Impact That Bullying At School Has on an Individual'S Self-Esteem During Young Adulthood,” Int. J. Educ. Res., vol. 1, no. 8, pp. 1-16, 2013.

[22] J. Goodman, J. Medaris, K. Verity, and B. Hott, "A Synthesis of International School-Based Bullying Interventions.," J. Spec. Educ. Apprenticesh., vol. 2, no. 2, 2013.

[23] D. Karim, "Managing conflict by school leadership: A case study of a school from GilgitBiltistan,” Int. J. Innov. Res. ..., vol. 2, no. January, pp. 340-343, 2015.

[24] H. A. Wani, "Understanding conflict resolution," Cent. Promot. Ideas, vol. 1, no. January 2011, pp. 104-111, 2011. 